\title{
Accounting
}

\section{Exploring the internal factors influencing financial distress}

\section{Kuat Waluyo Jatia, Linda Agustina ${ }^{a}$, Muhammad Ihlashul Amal ${ }^{a^{*}}$, Indah Fajarini Sri Wahyuningrum ${ }^{a}$ and Zulaikha ${ }^{b}$}

\author{
${ }^{a}$ Accounting Department, Faculty of Economics, Universitas Negeri Semarang, Indonesia \\ ${ }^{b}$ Accounting Department, Faculty of Economics and Business, Diponegoro University, Indonesia
}

\section{H R O N I C L E}

\section{Article history:}

Received: November 28, 2020

Received in revised format:

December 282020

Accepted: February 3, 2021

Available online:

February 3, 2021

Keywords:

Internal Factors

Financial Distress

Financial Factors

Ownership Structure

\section{A B S T R A C T}

This study aims to examine the effects of different factors influencing on financial distress. The population of this study includes industrial companies listed on the Indonesia Stock Exchange. Samples were processed by choosing 69 companies for three years of information which leaves us to have 150 observations. The sampling technique uses purposive random sampling and data is analyzed using PLS. The results show that firm size and liquidity negatively affect the financial distress while leverage positively affects the financial distress. In addition, institutional ownership moderates liquidity towards financial distress, firm size negatively affects liquidity, and liquidity does not mediate the effect of firm size on financial distress. The conclusion of this research is that management teams can avoid financial distress if they are able to manage liquidity ratios and leverage well, both ratios must be maintained so that they would not exceed firms' financial abilities. Companies with big amount of total assets have an advantage in competition since it is not overshadowed by the condition of financial distress and they can easily gain stakeholders' confidence. Institutional ownership in this study seems to encourage management to take risks related to company liquidity to generate profits by utilizing long-term debt in financing its operations.

(C) 2021 by the authors; licensee Growing Science, Canada

\section{Introduction}

Financial distress describes the condition of companies that are experiencing poor financial situations. Brahmana (2007) explained that a company can experience financial distress if the company's performance shows a negative net profit, operating profit, and book value of equity, and a company conducting merger. Companies that experience financial distress cause concern for internal parties such as managers and employees, as well as external parties such as investors and creditors. The investor gets risks to lose their shares invested in the company and the creditors suffer losses from their fund they have lent. This makes bankruptcy prediction analysis (financial distress) indispensable in making investment decisions (Yuliastary \& Wirakusuma, 2014). Financial distress or financial distress can be identified through information reported by the company. According to Hanafi and Halim (2012:259) financial distress information can be useful for various parties, such as lenders, investors, governments, accountants, and especially management. If management can detect bankruptcy early, then actions to help the situation can be taken so that bankruptcy can be avoided.

* Corresponding author.

E-mail address: amal@mail.unnes.ac.id (M. I. Amal) 
There are quite a lot of phenomena related to financial distress in Indonesia, such as the case of PT Nyonya Meneer being declared bankrupt because it was unable to pay debts of Rp252 billion (Kompas.com, 2017). Sariwangi Tea Company also experienced a debt default of Rp1 trillion (Kompas.com, 2018). Bankruptcy was also experienced by the Amplop Jaya producer, Royal Standard Group, because it was in the process of Deferring Debt Payment Obligations with a bill of Rp 351.4 billion (Kompas.com, 2018). PT Tiga Pilar Sejahtera Food was bankrupt with a total debt cancellation of debt obligations (PKPU) worth more than Rp 498 billion (Kompas.com, 2019). In the 2015-2018 period, the Indonesia Stock Exchange (BEI) pulled out eight company shares because it did not provide financial reports in accordance with the provisions and this indicated the company's poor financial performance and unable to maintain the company's going concern in the future (Okezone.com, 2018). Based on this phenomenon, it can be seen that several companies went bankrupt because they failed in managing their finances. The company's debt is compounded with the hope of being able to improve operations but in the end is unable to pay off the debt. Previous research related to financial distress was conducted by several researchers, such as Swalih et al. (2021), Triwahyuningtias and Muharam (2012), Mahtani and Garg (2018), Sari and Putri (2016), Widhiari and Merkusiwati (2015), Atika et al. (2013), Khaliq et al. (2014), Thim, et al. (2011), Andre (2013), Saleh and Sudiyatno (2013), Hapsari (2012), Mas'ud and Srengga (2012), Rahayu and Sopian, (2017), Ayu, et al. (2017), Gobenvy (2014), Radifan and Yuyetta (2015), Masdupi et al. (2018), and Prasetyo and Fachrurrozie (2016). Many variables have been studied that are predicted to affect financial distress in the study. But it still shows different results. Basically, in previous research literature, variables that are predicted to affect financial distress can be categorized into two categories, internal factors, and external factors. Some of these researchers examine the internal factors and external factors of financial distress in a model.

This study aims to examine the factors that influence financial distress that are seen from within the company. This study focuses on variables from within the company because if the company from the inside is not good in its management, with external conditions as well as anything will fall in conditions that cause a financial difficulty. This needs to be done because the research findings of Mahtani and Garg (2018) show that internal factors are the main and most influential factor in financial distress. This research is different from prior studies because in addition to focusing on internal factors it examines institutional ownership in a model and relates it only to liquidity. This is necessary for two reasons. First, the institutional owner is very concerned about how the company's ability to be able to pay its short-term obligations, in other words how the company's going concern for the next year becomes the focus because it can lead to an unpleasant audit opinion. Second, liquidity or the ability to pay short-term debt the company has received serious attention from practitioners and academics related to the risk of rollover when credit supply is low where the company cannot rollover debts due to liquidity on the credit market such as the 2008-2009 global financial crisis (Altman et al., 2019). This research is based on agency theory and signal theory. Agency theory explains that shareholders' interests and management conflict. Management's responsibility as an agent is to optimize the profits of shareholders, but on the other hand tends to prioritize personal goals. This makes the manager take action outside the knowledge of shareholders who violate the agreement by not always in the best interests of shareholders. Signal theory explains that the information conveyed by companies is a signal to users of financial statements. Financial statement information includes both positive and negative information. Negative information is characterized by a decline in financial performance on the financial statements. Information on the deterioration of financial conditions is expected to help users of financial statements, especially managers, so they can immediately take action to prevent bankruptcy.

Company size can be understood as a measure that describes the size of a company that can be seen from the size of the assets owned (Setyobudi et al., 2017; Rahayu \& Sopian, 2017; Gobenvy, 2014). The size of the company can provide different responses from various stakeholders to the company, this is consistent with what is explained in the signal theory. The bigger the company, the more it shows the size of the business and its market share, thus giving a signal to stakeholders that it is very unlikely that the company will experience a financially depressed condition (Tinoco \& Wilson, 2013; Charalambakis \& Garrett, 2019; Waqas \& Md-rus, 2018).

\section{$\mathbf{H}_{1}$ : Firm size has a negative effect on financial distress.}

Large companies have various advantages compared to small sized companies. As the total assets of the company increase, the level of ease of obtaining funds from the capital market will increase, bargaining power (bargaining power) in financial contracts will increase, and there is the possibility of the influence of scale in costs and returns to make larger companies can get more profit. Large size companies have a greater chance to win competition or survive in the industry (Sugiono \& Christiawan, 2013). Competition between companies is not only in terms of sales but also in the search for funds to carry out operational activities. The strength of the company makes it easier to get outside funding sources, so that it will be easier to get a loan. The confidence of outsiders in providing loan funds because the company is considered capable of carrying out financial management processes so as to obtain profits and this is proven by the greater assets owned by the company. However, large companies that are wellestablished will be easier to obtain capital in the capital market compared to small companies. The ease of access means the company has greater flexibility to choose and management will prefer funding from capital rather than funding from debt. 
Research by Mahtani and Garg (2018), Nugrahanti et al. (2020) and Das and Goel (2019) show support of what has been explained, so the hypotheses proposed are:

\section{H2: Company size has a negative effect on liquidity. \\ $\mathbf{H}_{3}$ : Firm size influences financial distress through liquidity.}

Liquidity compares short-term liabilities with short-term corporate resources (or current assets) available to meet those obligations. Liquidity is the current ratio that looks at the company's ability to meet short-term debt from its current assets. In other words, liquidity shows the company's ability to fund operational activities and pay short-term obligations (Chiaramonte \& Casu, 2017; Goulet \& Foster, 1980). Agency theory explains how company owners entrust the authority of financial management to managers, so that the decision to resolve liquidity problems is under the manager's control. If the manager does not perform as expected, the company will fall into financial distress because it fails to pay short-term debt. In this research, company liquidity is predicted to have a negative effect on the financial distress condition of a company because the company's inability to meet its current liabilities is a serious liquidity problem. Signal theory illustrates that managers so as not to give negative signals to stakeholders will take various steps to show that the company's finances are healthy. This can be done by selling forced investments and other assets that can lead to insolvency and bankruptcy difficulties. Supporting research from what is described include Almilia and Kristijadi (2003); Goulet and Foster (1980); and Andre and Taqwa (2014). The research hypothesis is:

\section{H4: Liquidity has a negative effect on financial distress.}

Leverage shows the company's ability to conform both short-term and long-term obligations. Analysis of this ratio is needed to measure the company's ability to pay debts (short-term and long-term) if one day the company is liquidated or dissolved (Goulet $\&$ Foster, 1980). This study predicts that there is a positive relationship between leverage and financial distress, which means that the greater the amount of debt, the greater the potential for companies to experience financial difficulties and bankruptcy (Lennox, 1999; Pasaribu, 2008). The idea underlying this relationship is bankruptcy usually begins with a moment of default due to an increase in the amount of debt. Signal theory illustrates that information about corporate debt will influence stakeholder responses. The response given can vary depending on how much debt the company has in terms of various financial ratios that are trusted by stakeholders. So, if a finance company uses more debt, this risks the risk of payment difficulties in the future due to debt greater than the assets owned. If this situation cannot be resolved properly, the potential for financial distress will be even greater. The research findings by Lakshan \& Wijekoon (2013), Charalambakis \& Garrett (2019), and Kazemian et al. (2017) support this explanation. So that, the hypothesis proposed is:

\section{H5: Leverage has a negative effect on Financial Distress.}

Creditors and owners have their respective tendencies in decision making related to debt realization. Creditors prefer a moderate current debt ratio because the lower the ratio, the lower level of risks. There will be a guarantee to cover losses or losses suffered by creditors will be smaller if liquidation occurs. Whereas the owner prefers a high debt ratio because it can increase profits for shareholders, if the company is successful it will give a very high return. However, high debt ratios reflect high risks, and this requires the right strategy to achieve company success. The success or failure of a company is more caused by strategies implemented by the company, such as corporate governance strategies. Corporate governance aims to ensure that company managers always take appropriate and selfless actions to protect the company's stakeholders. The implementation of a good corporate governance mechanism will minimize the risk of companies experiencing financial distress. The corporate governance mechanism analyzed in this study is institutional ownership. Institutional ownership, firm ownership structures, are significant contributors to investment decision making (Chou \& Johennesse, 2021). Institutional ownership is predicted to make managers focus on company performance, so as to reduce the opportunistic actions of company managers and increase effectiveness in the utilization of company assets (Cornett et al., 2009). With this mechanism, the funds available for company operations sourced from current debt are optimal. In addition, this study analyzes institutional ownership because the results of research conducted by Ananto et al. (2017) shows that institutional ownership has no effect on financial distress which is an indication that institutional ownership has a role as moderation rather than as an independent variable so the hypotheses formulated in this study are:

\section{H6: Institutional Ownership moderates the effect of liquidity on financial distress.}

\section{Methods}

This study uses secondary data. The observed object of this study is industrial companies listed on the Indonesia Stock Exchange (IDX) in the 2015-2017 period. Samples were obtained by purposive sampling. This study obtained 69 companies with 150 units of analysis as the samples after deducting outlier data. Table 1 shows the sampling criteria. 


\section{Table 1}

Determination of Samples

\begin{tabular}{lcc}
\hline \multicolumn{1}{c}{ Criteria } & $\begin{array}{c}\text { Does not meet } \\
\text { the criteria }\end{array}$ & $\begin{array}{c}\text { Meets the } \\
\text { criteria }\end{array}$ \\
\hline a. Industrial companies were listed on the Indonesia Stock Exchange in 2015-2017 period & 155 \\
b. Industrial companies that issue annual reports for the 2015-2017 period & $(14)$ & 141 \\
c. Companies with annual reports that contain interest expense information needed in research & $(55)$ & $(17)$ \\
d. $\quad$ Companies with institutional ownership that are not affiliated with the company & 69 \\
Number of years of observation & 3 \\
The company is the research sample & 69 \\
Total unit of analysis (3 years x 69 companies) & 207 \\
Outlier data during the study period & $(57)$ \\
Total research data for the 2015-2017 period & 150 \\
\hline
\end{tabular}

The dependent variable in this study is financial distress that is defined as several situations that clearly indicate a company's financial difficulties, such as failing to pay current legal obligations, for example, not paying bills (Sun et al., 2014; Ross et al., 2016) as measured by Interest Coverage Ratio (ICR) (Bhattacharjee \& Han, 2014). Independent variables include liquidity measured by Current Ratio (CR) (Bolek, 2013), leverage is measured by Debt to Equity Ratio (DER) (Raza, 2013), company size is measured by total assets (Cassar \& Holmes, 2003), and ownership Institutional measurement is measured by the number of shares of an institution divided by the number of shares outstanding (Koh, 2003). Liquidity refers to the company's ability to fulfill its short-term obligations (Niresh, 2012). Leverage is a relative proportion of debt and equity in financing company assets (Mahtani \& Garg, 2018). A low level of leverage ratio indicates high debt compared to the value of equity and a low level of leverage ratio is often found in companies that are experiencing financial distress. The size of the company is the size of the company in terms of the size of the assets owned (Ferri \& Jones, 1979). The amount of assets owned shows the company's ability to adapt to changing environments and competitive competition. Institutional ownership is the company's shares owned by the institution of the total outstanding shares of the company (McKnight \& Weir, 2009). The meaning of low ICR is the company is experiencing financial distress, if the ICR value is high then the company is not experiencing financial distress. Data collection uses documentation techniques. The data is taken from the sample company's annual report in the 2015-2017 period by downloading at idx.co.id. Data was analyzed using WarpPLS 6.0. Hypothesis testing can be done after the model meets the fit index.

\section{Results and discussion}

\section{Table 2}

Descriptive Statistics

\begin{tabular}{lccccc}
\hline & $\mathrm{N}$ & Minimum & Maximum & Mean & Std. Deviation \\
\hline Liquidity & 150 & .10 & 3.60 & 1.4711 & .69470 \\
Leverage & 150 & -1.25 & 3.58 & 1.1816 & .76811 \\
Firm Size & 150 & 25.80 & 31.83 & 28.4674 & 1.23443 \\
Institutional Ownership & 150 & .00 & .96 & .5749 & .28464 \\
Financial Distress & 150 & -7.81 & 15.58 & 3.1809 & 4.18761 \\
Valid N (listwise) & 150 & & & & \\
\hline
\end{tabular}

Hypothesis testing needs to pay attention to the fit index of the model. Table 3 shows that the model is good, and the model can be used to test hypotheses. The research model has an adjusted $\mathrm{R}^{2}$ value of 0.337 which means that financial distress variability can be explained by liquidity, leverage, firm size, and institutional ownership by $33.7 \%$. The variability of the other financial distress of $66.3 \%$ is explained by variables outside this research model.

Table 3

Evaluation of Structural Models

\begin{tabular}{|c|c|c|c|}
\hline Index & Score & Criteria & Remark \\
\hline $\mathrm{APC}$ & $<0.001$ & $\leq 0.05$ & Accepted \\
\hline ARS & 0.003 & $\leq 0.05$ & Accepted \\
\hline AARS & 0.004 & $\leq 0.05$ & Accepted \\
\hline AVIF & 1.372 & Ideal if $\leq 3.3$ & Acceptable \\
\hline AFVIF & 1.221 & Ideal if $\leq 3.3$ & Ideal \\
\hline Tenenhaus GoF & 0.447 & Big if $\geq 0.36$ & Big \\
\hline SPR & 1.000 & Acceptable if $\geq 0.7$ & Accepted \\
\hline RSCR & 1.000 & Acceptable if $\geq 0.9$ & Accepted \\
\hline SSR & 1.000 & Acceptable if $\geq 0.7$ & Accepted \\
\hline NLBCDR & 1.000 & Acceptable if $\geq 0.7$ & Accepted \\
\hline
\end{tabular}


The results of hypothesis testing can be seen in Table 4. Financial distress will decrease when the firm size is large, and the company's liquidity is in good condition. When the company's leverage increases, the company will experience financial distress. Firm size has a negative effect on company liquidity. Institutional ownership moderates the effect of liquidity on financial distress by weakening the effect while liquidity is not a mediation between firm size and financial distress. The research model can be seen in Fig. 1.

\section{Table 4}

Summary of Hypothesis Testing

\begin{tabular}{|c|c|c|c|c|c|}
\hline No & Hypothesis & Coefficient & P-value & $\alpha$ & Results \\
\hline 1 & Firm size has a negative effect on financial distress & 0.203 & 0.005 & 0.05 & $\mathrm{H}_{1}$ Accepted \\
\hline 2 & Firm size has a negative effect on liquidity & -0.211 & 0.004 & 0.05 & $\mathrm{H}_{2}$ Accepted \\
\hline 3 & Firm size influences financial distress through liquidity & -0.048 & 0.201 & 0.05 & $\mathrm{H}_{3}$ Rejected \\
\hline 4 & Liquidity has a negative effect on financial distress & 0.228 & 0.002 & 0.05 & $\mathrm{H}_{4}$ Accepted \\
\hline 5 & Leverage has a positive effect on financial distress & -0.221 & 0.003 & 0.05 & $\mathrm{H}_{5}$ Accepted \\
\hline 6 & $\begin{array}{l}\text { Institutional ownership moderates the effect of liquidity on financial } \\
\text { distress }\end{array}$ & -0.282 & $<0.001$ & 0.05 & $\mathrm{H}_{6}$ Accepted \\
\hline
\end{tabular}

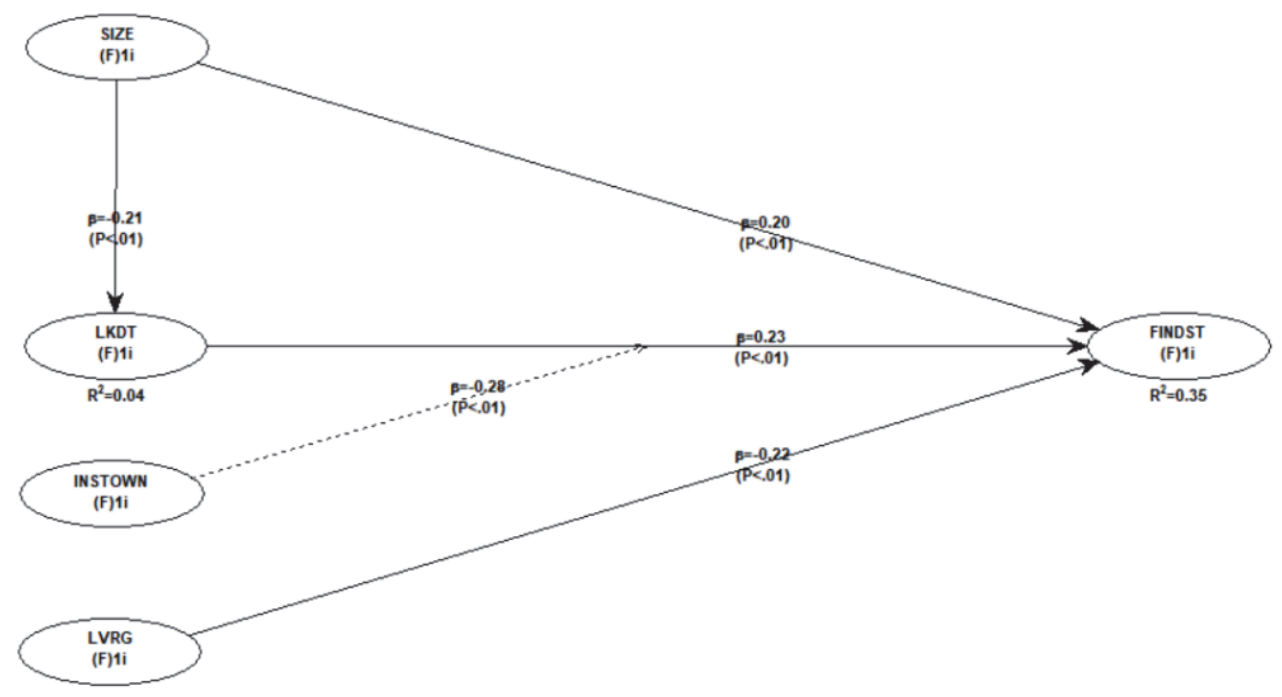

Fig. 1. Model of Research

\subsection{Effect of Firm Size on Financial Distress}

The size of the company is proven to have a negative effect on financial distress. This is evidenced by statistical results that reveal the increase of the company size causes the increase of the ICR. So that ICR which is getting bigger shows that it does not experience financial distress. These results are consistent with what is explained by the signal theory, that the size of the company will affect the response of stakeholders in looking at the condition of the company, one of which is financial condition. The greater the size of the company will give a signal that the company has a great ability to generate profits. This is because the company has a lot of resources that can be utilized to carry out company operations. A smooth company operation will certainly support greater sales, and this will ensure the safety of the company in the future. The results of this study are supported by some studies (e.g. Wilson, 2013; Charalambakis \& Garrett, 2019; Waqas \& Mdrus, 2018).

\subsection{Effect of Firm Size on Liquidity}

This research proves that the size of a large company will negatively affect liquidity. This happens because the larger companies, the more opportunities for companies to get funding sources other than debt. The large company is a signal to creditors that there will be no difficulty for the company to return borrowed funds. It also provides a signal for potential investors in the capital market. Prospective investors will be more interested in companies that have large company sizes, this can be understood because potential investors will assume that the large amount of assets owned by the company will be able to provide them the expected return from the company's operations. Returns from operations are an important source of cash availability (liquidity). Low operating returns are often associated with low liquidity. However, this still leaves uncertainty until the realization of the income itself. External financing is carried out only to anticipate revenue realization with the aim of maintaining the desired level of liquidity. Therefore, it is often found a high level of external financing in identic smaller companies with lower income than large companies. Research supporting this result is Kim et al., (1998) and Huberman (1984). 


\subsection{The effect of Firm Size on Financial Distress is mediated by liquidity}

Liquidity does not mediate the effect of firm size on financial distress that may be caused by the characteristics of the liquidity. Liquidity has two sides that must be maintained by the company, one side of the company must have a sufficient level to pay off its various current liabilities using its current assets. However, if a company maintains too many current assets, it will cause idle capacity of assets. Idle capacity of assets is not good because they make the company's performance not optimal. Industrial companies according to the Indonesia Stock Exchange (IDX) classification are companies that process raw materials into finished goods which are grouped into basic and chemical, various industries, and consumer goods industries. So that in carrying out its business activities, the production chain is long and influenced by various things. The multifarious industry sector is dominated by the capital-intensive automotive, textile and cable industries. Capital-intensive industries in the production process use sophisticated production machines so that they have more fixed assets in their asset structure, thus companies will need more long-term debt to finance their fixed assets (Widarti \& Sudanandra, 2014). Based on the conditions that have been explained, it can be understood that liquidity does not act as a mediation between firm size and financial distress in industrial companies in Indonesia. This is because industrial companies have more fixed assets than current assets to carry out their business activities and require long-term debt to finance or obtain these fixed assets. So that liquidity is not a concern of industrial company management to avoid financial distress, but it is more focused on how products from the production process using sophisticated machines can generate revenue because with the sale the company will be able to pay off its debts. Therefore, liquidity at industrial companies is only maintained at a certain level only to pay off current debts that arise, for example from the portion of long-term debt that is due in that year. This action is not specifically aimed at keeping the company from experiencing financial distress.

\subsection{Effect of Liquidity on Financial Distress}

The company's liquidity is proven to have a negative effect on financial distress. This means that the company can manage its finances well to guarantee that its short-term debts can be paid according to their time period. The ability of companies to pay short-term debt is a good thing because it shows a stable financial condition and can maintain trust of the creditor. In addition, these conditions also illustrate that the owner will not be disappointed because the company could provide the returns they expect and is able to realize revenue well so that the availability of cash to maintain the level of liquidity is guaranteed. Research supporting this result is Almilia \& Kristijadi (2003); Goulet \& Foster (1980); and Andre \& Taqwa (2014).

\subsection{Effect of Leverage on Financial Distress}

Leverage has a negative effect on financial distress. Signal theory illustrates that information about corporate debt will influence stakeholder responses. The response given can vary depending on how much debt the company has in terms of various financial ratios. If a company funds its operating activity by debt, the company will have payment difficulties in the future due to debt greater than the assets owned. The greater leverage means that the company has many liabilities for obtaining corporate funding that is not supported by the amount of assets owned by the company (Chrissentia \& Syarief, 2018). If this situation cannot be resolved properly, the potential for financial distress will be even greater. Lakshan \& Wijekoon (2013); Charalambakis \& Garrett (2019), and Kazemian et al. (2017) corroborate the results of this study.

\subsection{Effect of Liquidity on Financial Distress Moderated by Institutional Ownership}

Institutional ownership can moderate negative liquidity on financial distress, which means that currently the company's shares owned by the authorities will attach a liquidity license to ICR. Institutional ownership is part of corporate governance that guarantees the company runs, which benefits the owner (investor) as well as creditors in the context of purchasing all his debts. Industrial companies are capital-intensive companies that use a variety of sophisticated machinery to produce highly interested products whose products can be sold. Industrial companies are also strongly opposed by outside companies themselves, such as interest banks and the rupiah exchange rate. Bank interest that can be transferred with sales credit and the exchange rate of the rupiah related to the procurement of several production components obtained from abroad. The increase in the amount of interest that must be paid on sales will go down and decrease the value of the rupiah higher the amount that companies must incur to buy raw materials. The condition of industrial companies in Indonesia thus makes investors very concerned with companies that sell their products so that they make a profit, including company owners. Owners who have an interest in what is needed will question managers and ask them to pay close attention to the assets required for production and the long expenditure to finance them. Income obtained by the company will be used to support the fixed assets needed for production and budgeting policies issued by the company. This causes the company to have a smaller amount of assets with a larger amount of money that results from a higher amount of tempo and results in greater company liquidity. 
Institutional ownership can moderate negative liquidity on financial distress, which means that currently the company's shares owned by the institution will weaken the effect of liquidity on ICR. Institutional ownership is part of corporate governance that guarantees the company runs, which benefits the owner (investor) as well as creditors in the context of purchasing all his debts. Industrial companies are capital-intensive companies that use a variety of sophisticated machinery to generate massive products. They have an interest in making the goods sold. Industrial companies are also strongly opposed by outside companies themselves, such as interest banks and the rupiah exchange rate. Bank interest that can be transferred with sales credit and the exchange rate of the rupiah related to the procurement of several production components obtained from abroad. The inflation and the increase of the interest rate have an impact on the sales that sales will go down and decrease the value of the rupiah that means the higher the amount of dollar that companies must pay as incur to raw materials. The condition of industrial companies in Indonesia thus makes investors very concerned with companies that sell their products so that they make a profit, including company owners. Owners who have an interest in what is needed will question managers and ask them to pay close attention to the assets required for production and the long expenditure to finance them. Income obtained by the company will be used to support the fixed assets needed for production and budgeting policies issued by the company. This causes the company to have a smaller amount of assets with a larger amount of money that results from a higher amount of tempo and results in greater company liquidity.

\section{Conclusion}

The findings showed that firm size and liquidity have a negative effect on financial distress. This research also yields empirical results that institutional ownership is able to moderate the effect of liquidity on financial distress. Furthermore, the results also reveal that leverage has a positive effect on financial distress. In addition, the results showed that Firm Size has a negative effect on liquidity. However, the results of this study cannot support the hypothesis that stated liquidity mediates the effect of firm size on financial distress. The conclusion of this research is that management can avoid financial distress if it is able to manage liquidity ratios and leverage well, both ratios must be maintained so as not to exceed the ability limits that can be borne by the company. For companies that have a large total assets have an advantage in competition because it is not overshadowed by the condition of financial distress so that it can more easily gain stakeholder confidence. Institutional ownership in this study seems to encourage management to take risks related to company liquidity to generate profits by utilizing long-term debt in financing its operations.

\section{References}

Almilia, L. S., \& Kristijadi, E. (2003). Analisis Rasio Keuangan Untuk Memprediksi Kondisi Financial Distress Perusahaan Manufaktur Yang Terdaftar di Bursa Efek Jakarta. Jurnal Akuntansi \& Auditing Indonesia, 7(2).

Ananto, R. P., Mustika, R., \& Handayani, D. (2017). Pengaruh Good Corporate Governance (GCG), Leverage, Profitabilitas dan Ukuran Perusahaan Terhadap Financial Distress Pada Perusahaan Barang Konsumsi yang Terdaftar di Bursa Efek Indonesia. Jurnal Ekonomi dan Bisnis Dharma Andalas, 19(1), 92..

Andre, O. (2013). Pengaruh Profitabilitas, Likuiditas Dan Leverage Dalam Memprediksi Financial Distress (Studi Empiris Pada Perusahaan Aneka Industri yang Terdaftar di BEI). Jurnal Akuntansi, 1(1).

Andre, O., \& Taqwa, S. (2014). Pengaruh Profitabilitas, Likuiditas, dan Leverage Dalam Memprediksi Financial Distress (Studi Empiris Pada Perusahaan Aneka Industri yang Terdaftar di BEI Tahun 2006-2010). Jurnal WRA.

Atika, Darminto, \& Handayani, S. R. (2013). Pengaruh Beberapa Rasio Keuangan Terhadap Prediksi Kondisi Financial Distress. Jurnal Administrasi Bisnis, 1(2).

Ayu, A. S., Handayani, S. R., \& Topowijono. (2017). Pengaruh Likuiditas, Leverage, Profitabilitas, Dan Ukuran Perusahaan Terhadap Financial Distress Studi pada Perusahaan Manufaktur Sektor Industri Dasar dan Kimia yang Terdaftar di Bursa Efek Indonesia tahun 2012-2015 ). Jurnal Administrasi Bisnis (JAB), 43(1), 138-147.

Bhattacharjee, A., \& Han, J. (2014). Financial distress of Chinese firms: Microeconomic, macroeconomic and institutional influences. China Economic Review, 30, 244-262.

Bolek, M. (2013). Dynamic and static liquidity measures in working capital strategies. European Scientific Journal, 9(4).

Brahmana, R. K. (2007). Identifying financial distress condition in Indonesia manufacture industry. Birmingham Business School, University of Birmingham, United Kingdom.

Cassar, G., \& Holmes, S. (2003). Capital structure and financing of SMEs: Australian evidence. Accounting and Finance, 43(2), 123-147. https://doi.org/10.1111/1467-629X.t01-1-00085

Charalambakis, E. C., \& Garrett, I. (2019). On corporate financial distress prediction: What can we learn from private firms in a developing economy? Evidence from Greece. Review of Quantitative Finance and Accounting, 52(2), 467-491. https://doi.org/10.1007/s11156-018-0716-7

Chiaramonte, L., \& Casu, B. (2017). Capital and liquidity ratios and financial distress. Evidence from the European banking 
industry. British Accounting Review. https://doi.org/10.1016/j.bar.2016.04.001

Chou, T.-K., \& Johennesse, L.-A. (2021). Board characteristics, ownership structures and firm R\&D intensity. Accounting, 7, $635-644$.

Chrissentia, T., \& Syarief, J. (2018). ANALISIS PENGARUH RASIO PROFITABILITAS, LEVERAGE, LIKUIDITAS, FIRM AGE, DAN KEPEMILIKAN INSTITUSIONAL TERHADAP FINANCIAL DISTRESS. SIMAK. https://doi.org/10.35129/simak.v16i01.11

Cornett, M. M., McNutt, J. J., \& Tehranian, H. (2009). Corporate governance and earnings management at large US bank holding companies. Journal of Corporate finance, 15(4), 412-430.

Das, S., \& Goel, U. (2019). Determinants of Excess and Deficit Cash Holdings of Firms: Evidence from Emerging Market. Global Business Review. https://doi.org/10.1177/0972150918824950

Ferri, M. G., \& Jones, W. H. (1979). Determinants of financial structure: A new methodological approach. Journal of Finance, 34(3), 631-644. https://doi.org/doi:10.1111/j.1540-6261.1979.tb02130.x

Gobenvy, O. (2014). Pengaruh Profitabilitas, Financial Leverage Dan Ukuran Pperusahaan Terhadap Financial Distress Pada Perusahaan Mannufaktur Yang Terdatar Di Bursa Efek Indonesia Tahun 2009-2011. Jurnal Akuntansi, 2(1).

Goulet, P., \& Foster, G. (1980). Financial Statement Analysis. The Journal of Finance. https://doi.org/10.2307/2327225

Hanafi, M., \& Halim, A. (2012). Analisis Laporan Keuangan (4th ed.). UPP STIM YKPN.

Hapsari, E. I. (2012). Kekuatan Rasio Keuangan Dalam Memprediksi Kondisi Financial Distress Perusahaan Manufaktur di BEI. Jurnal Dinamika Manajemen, 3(2), 101-109.

Huberman, G. (1984). External financing and liquidity. The Journal of Finance, 39(3), 895-908.

Kazemian, S., Shauri, N. A. A., Sanusi, Z. M., Kamaluddin, A., \& Shuhidan, S. M. (2017). Monitoring Mechanisms and Financial Distress of Public Listed Companies in Malaysia. Journal of International Studies, 10, 92-109. https://doi.org/10.14254/2071-8330.2017/10-1/6

Khaliq, A., Altarturi, B. H. M., Thaker, H. M. T., Harun, M. Y., \& Nahar, N. (2014). Identifying Financial Distress Firms : A Case Study of Malaysia's Government Linked Companies (GLC). International Journal of Economics, Finance and Management, 3(3), 141-150.

Kim, C.-S., Mauer, D. C., \& Sherman, A. E. (1998). The Determinants of Corporate Liquidity: Theory and Evidence. The Journal of Financial and Quantitative Analysis. https://doi.org/10.2307/2331099

Koh, P. (2003). On the association between institutional ownership and aggressive corporate earnings management in Australia. 35, 105-128. https://doi.org/10.1016/S0890-8389(03)00014-3

Kompas.com. (2017). Utang PT Nyonya Meneer ke Kreditor Capai Rp 252 Miliar. Kompas.Com.

Kompas.com. (2018a). Majelis Hakim Putuskan Produsen Amplop Jaya Pailit. Kompas.Com.

Kompas.com. (2018b). Utang Rp 1 Triliun, Perusahaan Teh Sariwangi Dinyatakan Pailit. Kompas.Com.

Kompas.com. (2019). Mengurai Permasalahan dan Isu Pailit yang dialami Produsen Taro. Kompas.Com.

Lakshan, A. M. I., \& Wijekoon, W. M. H. . (2013). The Use of Financial Ratios in Predicting Corporate Failure in Sri Lanka. GTSF Journal on Business Review (GBR), 2(4). https://doi.org/10.5176/2010-4804

Lennox, C. (1999). Identifying failing companies: A reevaluation of the logit, probit and DA approaches. Journal of Economics and Business. https://doi.org/10.1016/s0148-6195(99)00009-0

Mahtani, U. S., \& Garg, C. P. (2018). An analysis of key factors of financial distress in airline companies in India using fuzzy AHP framework. Transportation Research Part A: Policy and Practice. https://doi.org/10.1016/j.tra.2018.08.016

Mas'ud, I., \& Srengga, R. M. (2012). Analisis Rasio Keuangan Untuk Memprediksi Kondisi Financial Distress Perusahaan Manufaktur Yang Terdaftar Di Bursa Efek Indonesia. Jurnal Akuntansi Universitas Jember, 10(2), 139-154.

Masdupi, E., Tasman, A., \& Davista, A. (2018). The Influence of Liquidity, Leverage and Profitability on Financial Distress of Listed Manufacturing Companies in Indonesia. Advances in Economics, Business and Management Research, 57(Piceeba), 223-228.

McKnight, P. J., \& Weir, C. (2009). Agency costs, corporate governance mechanisms and ownership structure in large UK publicly quoted companies: A panel data analysis. Quarterly Review of Economics and Finance, 49(2), 139-158. https://doi.org/10.1016/j.qref.2007.09.008

Niresh, J. A. (2012). Trade-off between liquidity \& profitability: A study of selected manufacturing firms in Sri Lanka. Researchers World, 3(4), 34.

Nugrahanti, Y. W., Sutrisno, T., Rahman, A. F., \& Mardiati, E. (2020). Do firm characteristics, political connection and corporate governance mechanism affect financial distress?(Evidence from Indonesia). International Journal of Trade and Global Markets, 13(2), 220-250.

Okezone.com. (2018). 15 Emiten Terancam Delisting dari Bursa. Okezone.Com.

Pasaribu, R. B. F. (2008). Penggunaan Binary Logit Untuk Prediksi Financial Distress Perusahaan Yang Tercatat Di Bursa Efek Jakarta (Studi Kasus Emiten Industri Perdagangan). Jurnal Ekonomi, Bisnis, Dan Akuntansi Ventura.

Prasetyo, R. A., \& Fachrurrozie. (2016). Analysis of Factors Effecting on The Probability of Financial Distress. Accounting Analysis Journal, 5(4), 370-380.

Radifan, R., \& Yuyetta, E. N. A. (2015). Analisis Pengaruh Mekanisme Good Corporate Governance Terhadap Kemungkinan 
Financial Distress. Diponegoro Journal of Accounting, 4(3), 1-11.

Rahayu, wiwin putri, \& Sopian, D. (2017). Pengaruh Rasio Keuangan Dan Ukuran Perusahaan Terhadap Financial Distress (Studi Empiris Pada Perusahaan Food and Beverage Di Bursa Efek Indonesia). Competitive Jurnal Akuntansi Dan Keuangan, 1(2).

Raza, M. W. (2013). Affect of financial leverage on firm performance. Empirical evidence from Karachi Stock Exchange.

Ross, S. A., Westerfield, R. W., Jordan, B. D., \& Roberts, G. (2016). Fundamentals of Corporate Finance (9th Canadi).

Saleh, A., \& Sudiyatno, B. (2013). Pengaruh Rassio Keuangan Untuk Memprediksi Probabilitas Kebangkrutan Pada Perusahaan Manufaktur Yang Terdaftar di Bursa Efek Indonesia. Dinamika Akuntansi, Keuangan Dan Perbankan, 2(1), 82-91.

Sari, N. L. K. M., \& Putri, I. G. A. M. A. D. P. (2016). Kemampuan Profitabilitas Memoderasi Pengaruh Likuiditas Dan Leverage Terhadap Financial Distress. Jurnal Riset Akuntansi, 6(1), 1-9.

Setyobudi, A., Amboningyas, D., \& Yulianeu. (2017). The Analysis Of Liquidity, Leverage, Profitability, and Firm Size Influence Toward The Financial Distress With Good Corporate Governonce as The Moderating Variable in PT. Telekomunikasi Indonesia Tbk.and PT. Indosat Tbk. Journal OfManagement, 3(3).

Sugiono, L. P., \& Christiawan, Y. J. (2013). Analisa Faktor yang Mempengaruhi Likuiditas pada Industri Ritel yang Terdaftar pada Bursa Efek Indonesia Tahun 2007-2012. Business Accounting Review, 1(2), 298-305.

Sun, J., Li, H., Huang, Q.-H., \& He, K.-Y. (2014). Predicting financial distress and corporate failure: A review from the stateof-the-art definitions, modeling, sampling, and featuring approaches. Knowledge-Based Systems, 57, 41-56.

Swalih, M. M., Adarsh, K. B., \& Sulphey, M. M. (2021). A study on the financial soundness of indian automobile industries using altman z-score. Accounting. https://doi.org/10.5267/j.ac.2020.12.001

Thim, C. K., Choong, Y. V., \& Nee, C. S. (2011). Factors affecting financial distress: The case of Malaysian public listed firms. Corporate Ownership and Control, 8(4), 345-351.

Tinoco, M.H., \& Wilson, N. (2013). Financial distress and bankruptcy prediction among listed companies using accounting, market and macroeconomic variables. International Review of Financial Analysis. https://doi.org/10.1016/j.irfa.2013.02.013

Triwahyuningtias, M., \& Muharam, H. (2012). Analisis Pengaruh Struktur Kepemilikan, Ukuran Dewan, Komisaris Independen, Likuiditas Dan Leverage Terhadap Terjadinya Kondisi Financial Distress (Studi Pada Perusahaan Manufaktur Yang Terdafatar Di Bursa Efek Indonesia Tahun 2008-2010). Diponegoro Journal of Management, 1(1), 1-14.

Waqas, H., \& Md-rus, R. (2018). Predicting financial distress : Importance of accounting and firm-specific market variables for Pakistan's listed firms. Cogent Economics \& Finance, 6(1), 1-16. https://doi.org/10.1080/23322039.2018.1545739

Widarti, A. A., \& Sudanandra, I. M. (2014). Pengaruh Karakteristik Perusahaan Terhadap Keputusan Pendanaan (Perbandingan Antar Sub Sektor Industri Manufaktur). Jurnal Siasat Bisnis, 18(2), 190-201.

Widhiari, N. L. M. A., \& Merkusiwati, N. K. L. A. (2015). Pengaruh Rasio Likuiditas, Leverage , Operating Capacity, dan Sales Growth Terhadap Financial Distress. E-Jurnal Akuntansi Universitas Udayana, 2, 456-469.

Yuliastary, E. C., \& Wirakusuma, M. G. (2014). Analisis Financial Distress Dengan Metode Z- Score Altman, Springate, Zmijewski. E-Jurnal Akuntansi Universitas Udayana, 6(3), 379-389. 
(C) 2021 by the authors; licensee Growing Science, Canada. This is an open access article distributed under the terms and conditions of the Creative Commons Attribution (CC-BY) license (http://creativecommons.org/licenses/by/4.0/). 